\title{
WHAT'S NEW IN THE 2019 ESC GUIDELINES ON CHRONIC CORONARY SYNDROMES?
}

\author{
Adriana llieșiu \\ "Carol Davila" University of Medicine and Pharmacy \\ "TH. Burghele" Clinical Hospital \\ Department of Internal Medicine and Cardiology
}

\begin{abstract}
The European Guidelines for Diagnosis and Treatment of Chronic Coronary Syndromes (CCS) were published in 2019 with a different title than the previous 2013 Guidelines that referred to "chronic stable coronary heart disease", underlining the dynamic nature of the atherosclerotic process. The main changes in these guidelines refer to the most frequent clinical presentations of CCS, to the assessment of the pretest probability of atherosclerotic coronary heart disease with the recommendation to include cardiovascular risk factors and other factors, as well as the choice of invasive anatomical and/or functional diagnostic tests, invasive and/or non-invasive, depending on the probability of the existence of the disease.

Regarding the treatment, these guidelines underline the importance of a healthy lifestyle and the modalities for the implementation and the strategy of anti-ischemic drug treatment, antithrombotic therapy being more widely addressed. Recommendations for myocardial revascularization on top of drug treatment for symptoms control and for improving prognosis are less restrictive in these guidelines. The recommendations of the CCS guidelines are harmonized with the recommendations of the other European guidelines, especially with those on diabetes, prediabetes and cardiovascular diseases which were also published in 2019.
\end{abstract}

Keywords: European Guidelines for Diagnosis and Treatment of Chronic Coronary Syndromes, atherosclerotic coronary heart disease, cardiovascular risk factors, treatment.

\section{Rezumat}

Ghidul european de diagnostic și tratament al sindroamelor coronariene cronice (SCC) a fost publicat în anul 2019 sub un titlu diferit față de ghidul din 2013 care se referea la "boală coronariană cronică stabilă", subliniindu-se astfel caracteristicile dinamice ale procesului aterosclerotic. Principalele modificări ale ghidului se referă la cele mai frecvente manifestări clinice ale SCC, la evaluarea probabilității pretest a bolii coronariene aterosclerotice, în care se recomandă includerea factorilor de risc cardiovascular și a altor factori, cât și la alegerea testelor diagnostice morfologice și/sau funcționale, invazive și/sau non-invazive, în funcție de probabilitatea existenței bolii.

În privința tratamentului se subliniază importanța unui stil de viață sănătos și modalitățile de 


\section{INTERNAL}

\section{General Reviews}

implementare a acestuia și se discută strategia tratamentului medicamentos anti-ischemic, terapia antitrombotică fiind mai larg abordată. Indicațiile de revascularizare miocardică asociată tratamentului medicamentos pentru controlul simptomelor și ameliorarea prognosticului sunt mai puțin restrictive. Recomandările ghidului SCC sunt armonizate cu recomandările celorlalte ghiduri europene, în special cu cele ale ghidului de diabet, prediabet și boli cardiovasculare, publicat tot în 2019.

Cuvinte cheie: Ghidul european de diagnostic si tratament al sindroamelor coronariene cronice, boală coronariană aterosclerotică, factori de risc cardiovascular, tratament.

The new version of the ESC Guidelines for the diagnosis and management of Chronic Coronary Syndromes (CCS) was launched in 2019 at the ESC Congress in Paris 6 years after the previous ESC Guidelines(1). This article will focus on the main changes of these new Guidelines compared to the previous ones published in $2013^{(2)}$.

One important change is the title of the 2019 Guidelines, "ESC Guidelines on Chronic Coronary Syndromes" compared to the 2013 "ESC Guidelines on Stable Coronary Artery Disease". "Chronic Coronary Syndromes" better characterize the concept of atherosclerosis, a changing and progressive process with unstable and stable phases even during asymptomatic periods. The atherosclerotic process is influenced by many factors which may destabilize, stabilize or even regress the disease, (eg. changes in lifestyle or in the pharmacological and/or revascularization treatment). These new Guidelines are centered on the diagnosis and the management of the most frequent CCS clinical presentations occurring mainly in the outpatient setting:

1. patients with angina and suspected coronary artery disease (CAD);

2. patients with new onset heart failure/left ventricular dysfunction and CAD;

3. asymptomatic and symptomatic patients with stabilized symptoms $<1$ year after an initial CAD diagnosis or revascularization;

4. asymptomatic and symptomatic patients with stabilized symptoms $>1$ year after an initial CAD diagnosis or revascularization;

5. patients with angina and suspected vasospastic or microvascular disease;

6. asymptomatic subjects in whom CAD is detected at screening. 
A major change in the 2019 CCS Guidelines is the assessment of pre-test probability of CAD. In the 2013 Guidelines the pre-test probability of CAD was based on different variables such as angina characteristics, sex and age. However, a pooled analysis of recent studies concluded that the CAD probability in this pre-test probability model was significantly overestimated (3). In countries with low risk of cardiovascular disease the pre-test probability of CAD in patients with chest pain was drastically reduced in 2019, having a prevalence of approximately onethird of that predicted by the model used in 2013 Guidelines. The results of different studies showed that patients with an updated pre-test probability less than $15 \%$ have good outcomes, with a risk of mortality or myocardial infarction less than 1\%/year. In these new Guidelines there is also added in the pre-test probability table a new column for patients without angina, but with dyspnea due to CAD.

Furthermore, the pre-test probability can be modified by the assessment of clinical likelihood of CAD. The presence of risk factors (e.g, smoking, diabetes, hypertension, dyslipidaemia), ECG changes at rest or during stress, ischemia-induced left ventricular dysfunction and coronary calcification have improved the diagnosis of CAD compared with chest pain, age and sex as standalone variables of the pre-test probability. The likelihood of obstructive CAD is low, less than $5 \%$, in patients with absence of coronary calcium at CT (computed tomography) (Agatston score 0).

A new major recommendation is the selection of the appropriate diagnostic tests for CAD based on the likelihood of disease: low, moderate, or high. Patients with high pre-test probability, with symptoms refractory to medical therapy or with typical angina at low threshold will benefit directly from invasive coronary angiography if they do not have severe comorbidities limiting their lifespan. Non-invasive functional tests of ischemia (stress echocardiography, SPECT, etc) are strongly recommended in patients with moderate to high likelihood of obstructive CAD. Functional test for myocardial ischemia are also recommended after coronary CT angiography (CTA) to detect the functional significance of the stenosis. It is a well-known fact that coronary stenosis estimated to be $50-90 \%$ are not necessary associated with inducible myocardial ischemia. CTA is particularly recommended in patients with low likelihood of obstructive CAD, due to the growing number of patients in whom CAD seems unlikely. On the other hand, CTA is becoming more and more used as a noninvasive anatomical test.

Exercise electrocardiography (ECG) was recommended as an initial diagnostic test for CAD in the previous Guidelines (class I recommendation). In the 2019 Guidelines, exercise ECG is considered an alternative test for the diagnosis of obstructive CAD when other non-invasive or invasive tests are not available. Thus, in the current CCS Guidelines exercise ECG test was downgraded to a class IIb recommendation. This changes in indication is based on the poor diagnostic performance of the exercise ECG which has very high risk of falsenegative and false-positive results, ruling-out CAD only in patients with very low risk and ruling-in CAD only in patients with very high risk. Therefore, the 2019 Guidelines recommend an imaging diagnosis test instead of exercise ECG for the diagnosis of obstructive CAD. However, the 2019 Guidelines underline that the selection of the initial non-invasive test should also be based on local expertise and the availability of the 


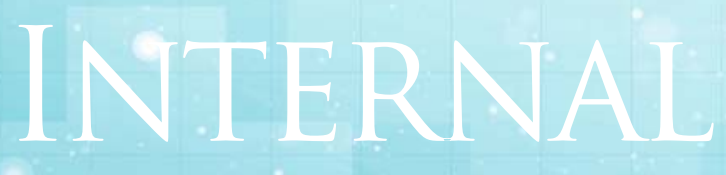

General Reviews

tests. In patients with documented CAD, however, the exercise ECG test is a useful tool providing valuable information about risk assessment (class I recommendation): exercise tolerance, symptoms, arrhythmias, blood pressure response to exercise and event risk in selected patients.

Invasive coronary angiography is indicated as an alternative test to diagnose $C A D$ in patients with high clinical likelihood of CAD and severe symptoms refractory to medical therapy, in patients with typical angina occurring at low level of exercise or in patients with left ventricular dysfunction presumed to be induced by CAD. In patients at high event risk event, even the symptoms are mild or absent, the invasive investigations are recommended for consideration of revascularization. Invasive coronary angiography performed via radial artery is preferred compared with the access by artery femoral due to its lower complication rates Revascularization is indicated in severe coronary stenosis (>90\%). In patients with coronary stenoses between $50-90 \%$ or with multivessel disease, the haemodynamic severity of coronary stenosis have to be demonstrated by invasive functional assessment using fractional flow reserve (FFR). The elective invasive coronary angiography completed with FFR evaluation has been established to change the management strategy in $30 \%$ to $50 \%$ of patients with CAD. Therefore, invasive coronary angiography with FFR is strong recommended (class I recommendation) for cardiovascular risk stratification in high-risk clinical symptomatic patients, especially when revascularization is expected to improve the prognosis and mitigate symptoms incompletely controlled by medical treatment.

As respect to the treatment strategy, the present Guidelines emphasize the importance of the implementation of healthy lifestyle behavior. Secondary prevention through lifestyle, diet, exercise and quitting smoking has been demonstrated to decreases the risk of cardiovascular events and mortality and should be part of the treatment in all of these patients. This aim requires cognitive behavioral interventions by multidisciplinary teams providing patients support to achieve healthy lifestyle changes. Anti-ischemic therapy needs to be individualized according to different factors (patient's heart rate, blood pressure, left ventricular function, comorbidities, other therapies, expected adherence, and the patient preferences). The first line drugs are beta-blockers (strongly recommended in patients with heart failure with reduced ejection fraction or with systolic dysfunction) and calcium channel blockers, either alone or in combination. Long-acting nitrates, a second-line treatment option, should be 
considered when first-line drugs are contraindicated, poorly tolerated or when angina is incompletely controlled. The nitrate prescription with a daily nitrate-free interval of $10-14 \mathrm{~h}$ is mandatory to avoid nitrate tolerance and loss of efficacy. The other second-line anti-ischemic drugs (nicorandil, ranolazine, ivabradine or trimetazidine) should also be used according to patient's characteristics.

Regarding the therapeutic strategies to event prevention, antithrombotic therapy was widely addressed in different scenarios: patients with CCS, with CCS after percutaneous coronary intervention ( $\mathrm{PCl}$ ), patients in sinus rhythm or in atrial fibrillation. In patients with previous myocardial infarction who have tolerated dual antiplatelet therapy for more than one year, long term treatment with aspirin and P2Y12 inhibitor should be considered if the risk of ischemic events is high and the risk of bleeding is low. Aspirin plus very low-dose rivaroxaban ( $5 \mathrm{mg}$ b.i.d.) could also be a therapeutic option in patients with previous myocardial infarction or with multivessel disease, in sinus rhythm, if they have a moderate-high risk of ischemic events and the low bleeding risk.

Myocardial revascularization has a less restrictive indication in the 2019 European CCS Guidelines. Myocardial revascularization on top of medical treatment is indicated for symptoms control and for the improvement of the prognosis. The risk-benefit ratio needs to be assessed in each patient. The choice for myocardial revascularization is illustrated in these Guidelines as a "decision tree" based on the presence or absence of symptoms, the non-invasive demonstration of a large area of ischemia ( $>10 \%$ ), the reduced left ventricular ejection fraction due to CAD ( $\leq 35 \%)$ and the hemodynamically significant coronary stenoses (with a significant intracoronary pressure gradient). Regarding the best options for the revascularization treatment, $\mathrm{PCl}$ or CAGB, the CCS Guidelines refers reader to the 2018 ESC Guidelines on Myocardial Revascularization

This new version of CCS Guidelines also embodies the recommendations of the 2019 European Guidelines on the management of diabetes, prediabetes, and cardiovascular diseases in patients with chronic CAD in an effort to synchronize the information from both Guidelines.

\section{References}

1. Knuuti J, Wijns W, Saraste $A$, et al. ESC Scientific Document Group. 2019 ESC Guidelines for the diagnosis and management of chronic coronary syndromes. Eur HeartJ. 2020; 41(3):407-477

2. Montalescot G, Sechtem U, Achenbach S, et al. 2013 ESC guidelines on the management of stable coronary artery disease: the Task Force on the management of stable coronary artery disease of the European Society of Cardiology. Eur HeartJ. 2013; 34(38):2949-3003.

3. Juarez-Orozco LE, Saraste $A$, Capodanno $D$, et al. Impact of a decreasing pre-test probability on the performance of diagnostic tests for coronary artery disease. Eur Heart J Cardiovasc Imaging 2019; 20(11):1198-1207 